\title{
Reply to: Zika Virus Infection, Pregnancy and Microcephaly
}

\section{Resposta para: Infecção por Vírus Zika, Gravidez e Microcefalia}

\author{
Geraldo Duarte ${ }^{1}$ \\ ${ }^{1}$ Universidade de São Paulo, Ribeirão Preto, Sao Paulo, Brazil \\ Rev Bras Ginecol Obstet 2018;40:54-55.
}

\section{Dear Editor,}

I would like to thank Dr. Sriwijitalai \& Wiwanitkit for the letter to the editor about our article on the care of pregnant women at the time of the zika virus infection. ${ }^{1}$ I would also like to thank you for the opportunity to clarify some of the topics they have mentioned.

About the statement 'If there are no complications (meningoencephalitis or Guillain-Barré syndrome), further examination is unnecessary to assess systemic impairment,' I inform that it is a sentence of the summary section, but reading the full text, you can find all of the explanations. ${ }^{1}$ It is pointed out there that these changes are serious, but atypical and rare. They are accompanied by severe dehydration, severe joint involvement, encephalitis, and GuillainBarré syndrome. These are serious complications that have the potential to cause maternal and fetal death. In all patients, despite no complications, if there is a clinical indication to evaluate the systemic compromise, subspecialty tests that evaluate the systemic response of the organism to the infectious agent will be indicated. The assistant doctor will be the one responsible to decide which exams will be necessary. In general, the blood count indicates moderate leukopenia and thrombocytopenia, helping in the differential diagnosis of bacterial infections. Thrombocytopenia indicates a higher probability that the infection is linked to the dengue virus. If necessary, exams to evaluate liver and renal function will be requested. It should be emphasized that, in the infection by the Zika virus, these serious cases are rare. Hemorrhagic syndromes, though possible, were not observed in the epidemic that occurred in Brazil over the last three years, and were not even accepted without reviews in the specific literature. $^{2}$

received

November 13, 2017

accepted

December 5, 2017
DOI https://doi.org/

$10.1055 / \mathrm{s}-0037-1617425$. ISSN $0100-7203$.
Address for correspondence Geraldo Duarte, Universidade de São Paulo, Avenida Bandeirantes, 3900, Ribeirão Preto, SP 14049-900, Brazil (e-mail: gduarte@fmrp.usp.br).

Yes, like you, we believe there is a percentage of asymptomatic cases of Zika virus infection, and that microcephaly is the epilogue to a vast process of damage to the embryonic and fetal nervous system. As some of these changes occur in the postnatal period, the adequate care offered to mothers affected by this infection should include guidance and the correct referral of "all children exposed to this infection," not only those with organic birth defects, as mentioned in paragraph three of the study by Duarte et al. ${ }^{1}$

I clarify that the paper in question had the objective of being a guideline for care of the Brazilian Association of Societies of Gynecology and Obstetrics (Febrasgo, in the Portuguese acronym) for pregnant women under the perspective of Zika virus infection, not for research. ${ }^{1}$ Screening all pregnant women and identifying those infected (but asymptomatic) may even be appropriate in some populations, but before adopting this behavior, firstly we must evaluate scientifically if the cost-benefit ratio will be proven satisfactory. Without these data, the national health system will, aptly, disagree with the screening. Secondly, there are no good serological tests in our country to safely screen these women.

On the use of anti-inflammatories, the sentence from the doctor's letter: "there is no contraindication to the use of anti-inflammatory drugs in the patients with dengue" is very worrying, because the risk of worsening any bleeding syndromes in dengue virus infection is real.

I agree that there is no evidence that the use of antiinflammatory drugs provides any clinical advantage in cases of Zika virus infection, but there is also no publication demonstrating otherwise if necessary. Our statement in that paper that "The use of antipyretics and common analgesics received

Copyright @ 2018 by Thieme Revinter

Publicações Ltda, Rio de Janeiro, Brazil
License terms

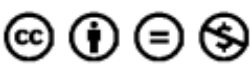


(dipyrone and acetaminophen) is recommended to control the febrile and painful symptoms." Until dengue infection is discarded, the use of acetylsalicylic acid or other non-steroidal anti-inflammatory drugs (NSAIDs) should be avoided, with support of the specific literature. ${ }^{3-8}$ If analgesics alone are needed, their use is the most appropriate management. However, if the inflammatory process requires a specific treatment, anti-inflammatory drugs are indicated.

\section{References}

1 Duarte G, Moron AF, Timerman A, et al. Zika virus infection in pregnant women and microcephaly. Rev Bras Ginecol Obstet 2017;39(05):235-248. Doi: 10.1055/s-0037-1603450

2 Musso D, de Pina JJ, Nhan TX, Deparis X. Uncommon presentation of Zika fever or co-infection? Lancet 2016;387(10030):1812-1813
3 Citil Dogan A, Wayne S, Bauer S, et al. The Zika virus and pregnancy: evidence, management, and prevention. J Matern Fetal Neonatal Med 2017;30(04):386-396

4 Picone O, Vauloup-Fellous C, D'Ortenzio E, et al. [Zika virus infection during pregnancy]. J Gynecol Obstet Biol Reprod (Paris) 2016;45(05):415-423

5 Simões R, Buzzini R, Bernardo W, Cardoso F, Salomão A, Cerri G. Zika virus infection and pregnancy. Rev Assoc Med Bras (1992) 2016;62(02):108-115

6 Hamel R, Liégeois F, Wichit S, et al. Zika virus: epidemiology, clinical features and host-virus interactions. Microbes Infect 2016;18(7-8):441-449

7 Shastry S, Koenig KL, Hirshon JM. Zika Virus: Critical Information for Emergency Providers. Emerg Med Clin North Am 2016;34(03): e25-e37

8 Centers for Disease Control and Prevention. Zika virus symptoms, diagnosis, and treatment. http://www.cdc.gov/zika/symptoms/ index.html (2016). Acessed in 2016 and 2017 